\title{
INTERSTATE COLLECTIVE SECURITY: ITS DEVELOPMENT AND DECLNE
}

\section{Lt I.J. van der Waag*}

The idea of collective security and its later development, the regional collective defence alliance, is particularly interesting in the light of our contemporary situation. Not only because the $::^{1+n}$ r failure of the first has led to the rise of the second, but because the defence alliance implies a reverting to the old balance of power, which was rejected during the First World War in favour of the collective security system, thus now forming a complete cycle.

\section{Conceptualization}

The father of modern collective security, American President Woodrow Wilson, said that "there must now be, not a balance of power, not one of powerful groups of nations set off against another, but a single overwhelming, powerful group of nations who shall be the trustee of the peace of the world".'

Different from the traditional concept of securing peace, that is through a fragile balance of power, collective security implies a total imbalance of power. Collective security further implies that peace is indivisible, and attack against one nation is an attack against all nations. Ideally this would scare any aggressor beginning a conflict from the fear of all the other states acting in concert against him. This has, however, not been the case with either the League of Nations or the United Nations. ${ }^{2}$

Collective security may be defined as "the creation of an international system in which the danger of aggressive warfare by any state is to be met by the avowed determination of virtually all other states to exert pressure of every necessary variety - moral, diplomatic, economic, and military - to frustrate attack on any state". Duchacek describes collective security as a grand alliance of all peace-loving states, who react against any aggressor who might disturb the peace at any time, and the identity of the aggressor is not known nor implied. ${ }^{3}$

Clearly reflected in the origins of the League of Nations, a further facet is the maintenance of the status quo. Thus an aggressor state would face the sanction of all the other states determined to maintain the status quo, much as Britain and France were determined to maintain the status quo after the First World War. Unfortunately, like al! status quo-oriented systems, collective security ignores the dynamics of political, social and economic change. ${ }^{4}$

There are two basic co-operative techniques of checks and balances:

1. Bilateral and multilateral alliances. As first embodied in the covenant of the League of Nations under article 16 and then in the United Nations Charter in chapter vii (articles 39 to 51), the concept of collective security was supposed to make peace secure and alliances unnecessary; ${ }^{5}$

2. Collective security. After the Cold War collective security became practically impossible, making way for the resurrection of regional collective defence systems and aliances.

Collective security is a complex concept that has become difficult to define due to the many different approaches states prefer to make. According to Hartman, three new meanings of collective security have arisen. Firstly, the utopian idea of a universal alliance making an end to war; secondly, the "big-power dictatorship" seen in the League of Nations and intended by the three architects of the United Nations; and thirdly, the network of alliance systems of the polarized world after 1945, which have become known as regional security alliances. ${ }^{6}$

As stated, the nature of collective security is such, that if $A$ threatens $B$, then $C, D, E, F, G, H, I$, $\mathrm{J}$, and $\mathrm{K}$, will take steps against $\mathrm{A}$, just as if $A$ had threatened them.

1. M.V. Naidu: Collective Security and the United Nations, p. 4.

2. I.D. Duchacek: Nations and Men; International Politics Today, p. 348.

3. Ibid., p. 340.

4. O. Pick and J. Critchley: Collective Security, pp. 29-30.

5. I.D. Duchacek, op cit., p. 348.

6. F.H. Hartman: World in Crisis; Reading in International Relations, p. 154. 


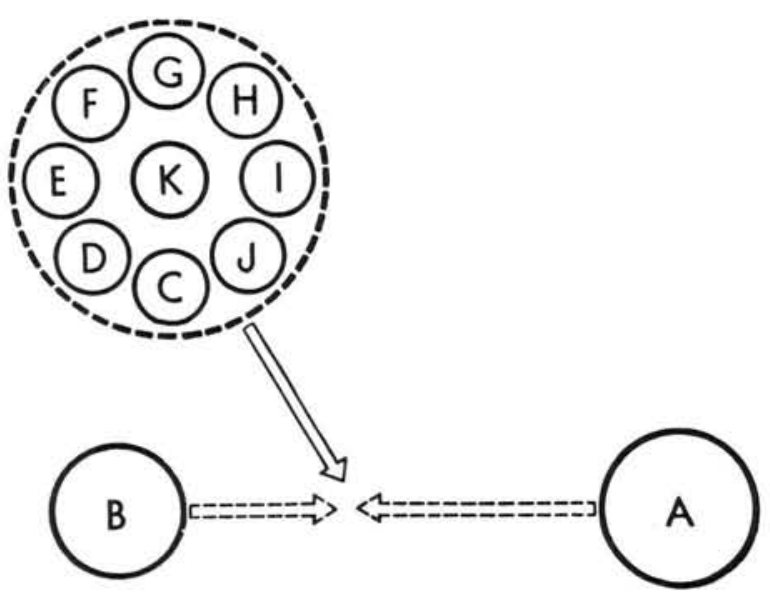

Figure 1: The Ideal of Collective Security (H.J. Morgenthau: Politics Among Nations).

Three assumptions must be fulfulled for collective security to effectively prevent war: (1) "the collective system must be able to muster at all times such overwhelming strength against any potential aggressor or coalition of aggressors that the latter would never dare to challenge the order defended by the collective system; (2) at least those nations whose combined strength would meet the requirement under (1) must have the same conception of security which they are supposed to defend; (3) those nations must be willing to subordinate their conflicting political interests to the common good defined in terms of the collective detence of all member states"? The chance of all these assumptions being realized in any particular situation is very slım. It is unlikely that in any situation only one nation might be labelled the aggressor, and many more nations are likely to sympathize with the aggressors. Therefore collective security can only succeed on the further assumption that all the nations will come to the defence of the status quo when threatened, regardless of their internal or foreign policies. As collective security must work under these ideal assumptions, it is virtually impossible that it will ever work with any effect in our contemporary world. For example, "if A attacks $B$, then $C, D, E$, and $F$ might honour their collective obligations and come to the aid of $\mathrm{B}$, while $\mathrm{G}$ and $\mathrm{H}$ might try to stand aside and I, J, and $\mathrm{K}$ might support $\mathrm{A}$ 's aggression." ${ }^{8}$

Should there have been no collective system, the war might have been contained between states $A$ and $B$, but under a collective security system operating under less than ideal conditions, the war is diffused among all or most of the states.

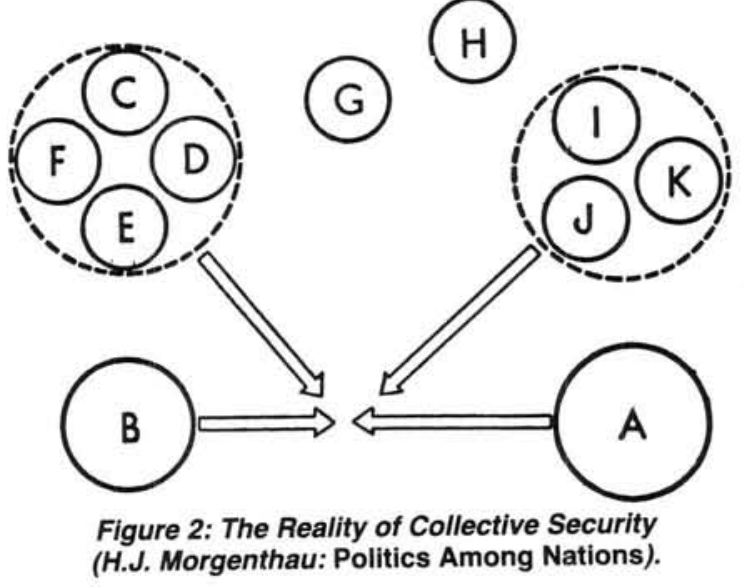

Historical development

The concept of collective security is tightly interwoven with that of the alliance, and to study the origins of the one requires the study of the origins of the other. Collective security is a development on the idea of an alliance. A defensive alliance usually counteracts a contending alliance or some external threat. Collective security, going a step further, implies that the threat is an internal one, and due to the absence of alliances, it is left to all the states to act in concert against the aggressor state. Hence, collective security developed from the notion of a universal alliance.

The concept alliance is as old as that of politics itself. The ancient Greek city states formed leagues against their enemies, and the smaller city states, in an attempt to survive, allied themselves in a defensive collectivity against the more powerful city states of Athens and Sparta. ${ }^{9}$ Sixteenth century Europe saw a Balance of Power, where no one state dominated the rest, replace the medieval idea of a universal hierarchy of states under the authority of the Holy Roman Emperor as leader of the known world. Throughout the Middle Ages the most important means of controlling international war, was the maintenance of this delicate balance of power and many wars were fought to adjust, preserve or restore it. ${ }^{10}$ In 1815 at the Congress of Vienna, a closer hold on international relations was attempted. It was decided that the four European super powers - Britain, Austria-Hungary, Prussia

7. Morgenthau, H.J., Politics Among Nations - a struggle for power and peace, p. 398.

8. Ibid., pp. 401-2.

9. O. Pick and J. Critchley: Collective Security, p. 21

10. Ibid., p. 22 
and Russia - should return the status quo of Europe to that before the time of Napoleon; that all the states of Europe should endeavour to prevent another general European war and the occurance of revolutions or violent attempts to overthrow the status quo; and finally to localize any war that might break out in the future. ${ }^{11}$

This Congress system, or "Concert of Europe" as it is better known, worked with some effect until 1825, when the Great Powers broke up on bad terms after the Congress of St. Petersburg.

This marked the end of the congress system, to which British Foreign Secretary, George Canning, listed three objections:

1. periodic reunions of powers were highly dangerous;

2. the congress system established general intervention by force in the internal affairs of different states, and

3. small powers were not represented and their rights were likely to be disregarded or overridden.

Canning would have had no objection to a congress limited to a policy of "moral solidarity", consulting the wishes of small powers, and disclaiming the use of force. The system did, however, have merits:

1. the idea of personal conference and mutual confidence between rulers was good, although after 1820, the system became a 'trade-union' of kings for suppressing the liberties of people;

2. the Great Powers could meet without embarrasment and effect lasting good, because each respected the institutions and difficulties of the other. ${ }^{12}$

After the failure of the Congress System, Europe returned to the traditional balance of power, consisting of an intricate, and sometimes conflicting, network of alliances and treaties. The problem even Otto von Bismarck, a master alliance maker, could not solve, was how to remain on good terms, or in alliance, with both Austria-Hungary and with Russia at the same time. Russia eventually signed the Dual Alliance (1893) with France, which now opposed the Triple Alliance Germany, Italy, and Austria-Hungary - and therefore Germany had a formidable enemy on both flanks. Europe, in similar circumstances today, was divided into two camps and each was necessarily an armed one.
Grant and Temperley summarize the situation as follows:

"It was because other states had joined one or other of the contending groups, and the quarrels of two states involved all the Great Powers and three quarters of Europe. France, dreaming of Alsace-Lorraine, had bound herself to Russia. Germany fearing both had joined with Austria-Hungary. England, disliking Germany's naval programme, had drawn close to Russia and France. A series of antagonisms between pairs of states, none of them necessarily formidable in themselves, had divided Europe into hostile camps, and each great armed group watched the other with suspicion, till finally, the guns went off by themselves". ${ }^{13}$

British politicians suggested that states should collectively abstain from war, long enough to settle the crisis by negotiation. It was further suggested that this could only be done by accommodating the United States in the balance of power. The British aimed at restoring and formalizing the old Congress System of the Concert of Europe, reinforced by the United States. American President Woodrow Wilson argued that if all the states could collectively act against aggression, the world would become more secure, and thus became the father of modern collective security. ${ }^{14}$

\section{Problems of Collective Security}

In order for Collective Security to be successful, a number of conditions have to be adhered to. Firstly, the nations who have the power to coerce would have to agree as to who is the aggressor and who is the victim. Secondly, after having reached an identical conclusion as to the identity of the aggressor and of the victim, the nations would have to act willingly and readily. And thirdly, collective security implies that nations have to act collectively against the aggressor whether he is friend or foe. Obviously, this is very unrealistic, as helping an enemy against a friend can only be detrimental to oneself. ${ }^{15}$

11. Grant, A.J., and Temperley, H.: Europe in the Nineteenth and Twentieth Centuries, pp. 137-9.

12. Ibid., pp. 143-4.

13. Ibid., p. 354

14. Pick, O., and Critchley, J., op cit., pp. 25-6.

15. Duchacek, I.D.: Nations and Men; International Politics Today, pp. 348-9. 
1. Institutionalization. All member states must recognise and accept the organs and procedures of collective security as legitimate sources of policy, even when they do not agree with the policy. This is seldom, if ever, done in reality. An example being South Africa's occupation of South West Africa despite UN sanctions. ${ }^{16}$

2. Equality of States. As in Metternich's Congress System, small states still cannot stand up against super powers in the UN, except in exceptional cases, such as Yugoslavia's stance against the USSR in $1948 .{ }^{17}$ Further, those states who wish to change the status quo may be more numerous or more powerful than those states interested in the maintenance of the status quo. It is also possible that two or three states can be more powerful than the rest of the world, as in the case of the USA, the USSR, and China trio.

3. The costs and risks of collective security. The economic costs of maintaining an armed security are very high, and smaller states may become fearful of being drawn into disputes by being allied to a super power who has a wide range of interests. ${ }^{18}$

4. Divided Loyalties. Some members of regional alliances may have interests outside the area of the alliance and divert resources to those other areas.

5. Lack of coercive power. Those states interested in maintaining the status quo very often do not have the power to sanction deviant states insistent on changing the status quo. ${ }^{19}$

6. The use of force. The concept of collective security contains a paradox: if peace is to be maintained, how can force be used to limit aggression? Furthermore, a show of force seems to imply politics without tactic, and the world's many pacifists who object to military preparedness on moral grounds, create further problems. ${ }^{20}$

7. The problem of defining aggression and identifying the aggressor. It is sometimes, but not always, possible to identify an aggressor. Most people agree that Adolf Hitler, for example, was the aggressor in 1939, but then one cannot really identify the aggressor in the Arab-Israeli Six Day War. Both the League of Nations and the United Nations, have failed to get agreement on aggression. ${ }^{21}$

\section{Examples of Collective Security}

In contemporary history there have been only two examples of collective security, namely the League of Nations and the United Nations; and any discussion of collective security would not be complete without a brief discussion of these organizations, and their failure.

\section{The League of Nations and the Italo- Ethiopian War}

The League of Nations was troubled by the same difficulties which trouble the United $\mathrm{Na}$ tions today. The League consisted of a number of sovereign states, without whose consent the league could not be bound. Important issues, especially those concerning collective action, had to be decided on by unanimous agreement, which was practically impossible, considering the fact that the super powers followed conflicting policies outside of the League. ${ }^{22}$

The classic example of the failure of the League is the Italo-Ethiopian War of 1931. The United States, Germany and Japan were not members of the League and divided their sympathies. Germany and Japan, who designed on overthrowing the status quo in their respective regions, encouraged the crisis, as this would weaken the position of Britain and France, who were endeavouring to preserve the status quo. The USA agreed with the maintaining of the status quo, but American public opinion prevented it from taking an active part. The ideal of collective security versus Italy, was therefore, the case of Britain and France versus Italy. This was far from the ideal, and Britain and France backed down. ${ }^{23}$ This resulted in the overthrow of the status quo in East Africa; the alliance of Italy and Germany; and the destruction of the collective security system in the League of Nations. ${ }^{24}$

\section{The United Nations and the Korean War}

A different solution was tried after the Second World War. The victors - Britain, United States,

16. Ernst, B. Haas: Tangle of Hopes: American Commitments and World Order, p. 75.

17. Pick, O., and Critchley, J.: Collective Security, p. 15.

18. Van Dyke, Vernon: International Politics, p. 341.

19. Pick, O., and Critchley, J.; op cit., p. 28.

20. Ibid., p. 18

21. Van Dyke, Vernon: op cit., p. 344.

22. Rodee et al: Introduction to Political Science, p. 494.

23. Margenthan, H.J.: Politics Among Nations, pp. 403-4.

24. Ibid., p. 404 


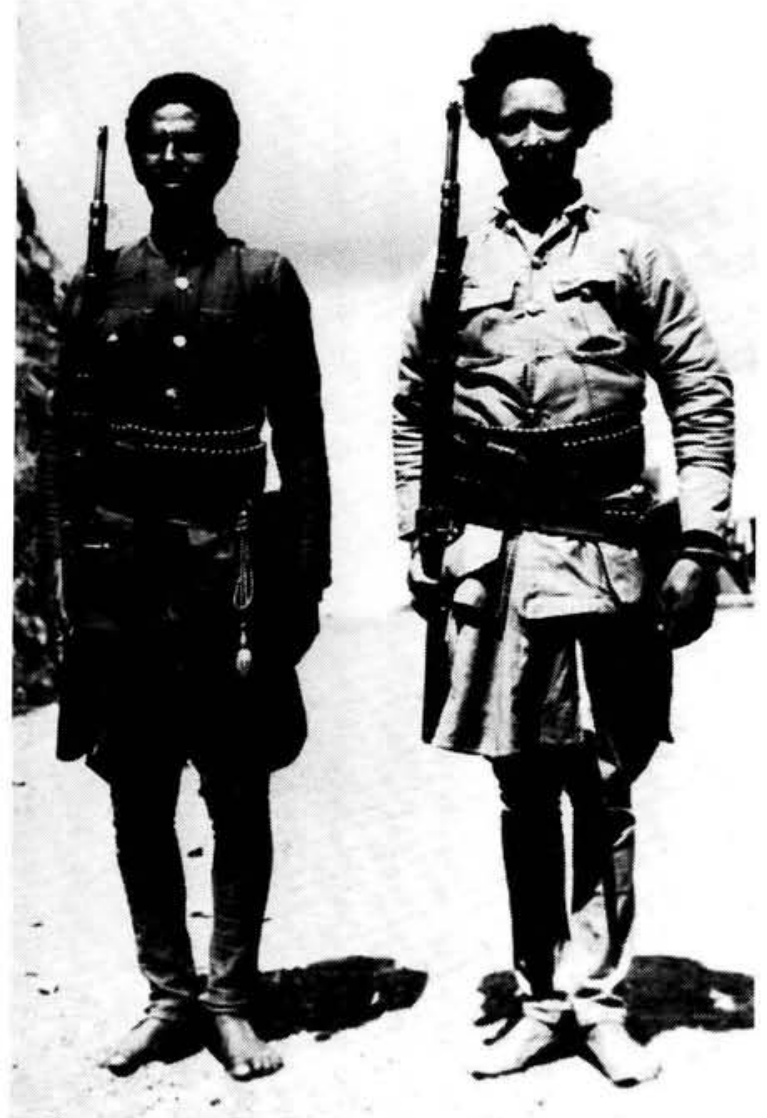

Dwindling collective security left the Ethiopians isolated in the struggle following the Itallan invasion of their homeland (SAAF Museum).

and Russia - again set up a collective system, which was handicapped from the beginning by the illusions of its founders. The assumption that the victors would continue to co-operate, never became reality. The emergence of the cold war soon after the inception of the United Nations, soon made it obvious that the international system, as laid down in the UN Charter, was heading for destruction. ${ }^{25}$

The Korean War marked the failure of the United Nations. Without doubt, collective security would have required that all the states come to the aid of South Korea, whose territory was being violated by North Korea. Of the sixty states represented in the UN, only sixteen sent armed forces of any kind, many of which being only token forces. Communist China joined North Korea, the aggressor, and many member states of the UN, with military capabilities, played no active part in the conflict. ${ }^{26}$

Along with the Congo crisis of 1960, the Cyprus Crisis and the Vietnam War, for all practical purposes, portrays the end of collective action in the United Nations, if there ever was such a thing.

\section{Collective Security and Regional Security Alliance}

Although many people refer to alliances as collective security measurements, according to the UN Charter, alliances should be referred to as collective self-defence treaties. These treaties have been authorized by the UN Charter (Artices 51,53 , and 107) for two reasons:

1. to permit the continuation of defence alliances against the enemies of the Allies in case of their return to aggressive policies; and

2. to provide nations with a legitimate means of collective self-defence as a stop-gap before the collective security mechanism, based on the unanimity of the five great powers, is organised."27

However, Article 51 of the UN Charter, states that collective defence action can continue until the Security Council of the UN takes steps to restore peace and security. ${ }^{28}$

The regional self-defence system is a compromise between the old balance of power, which became outdated during the First World War, and the universal collective security. According to Pick and Critchley "the ideals of universalism, culminating in world government are obviously not within the realm of practical politics, and as it is impossible to diffuse collective security across the whole wide world, the next best thing is to try and maintain it on a regional basis." 29

A regional collective security alliance may be considered a small-sized collective security system if it fulfils three basic requirements:

1. its membership includes most, if not all the states in the region;

2. it is permanently institutionalized with centralized authority and objective rules and procedures, and

3 . it guarantees the security of one member against another member, thereby maintaining peace and order among the member states only; that is, it is an inner-directed and inward-looking system. ${ }^{30}$

25. Rodee et al; op cit., p. 495.

26. Morgenthau, H.J.: op cit., pp. 404-5.

27. Duchacek, I.D.: Nations and Men, p. 355.

28. Ibid., p. 355.

29. Pick, O., and Critchley, J.: Collective Security, p. 45.

30. Naidu, M.V.: Collective Security and the United Nations, p. 16. 


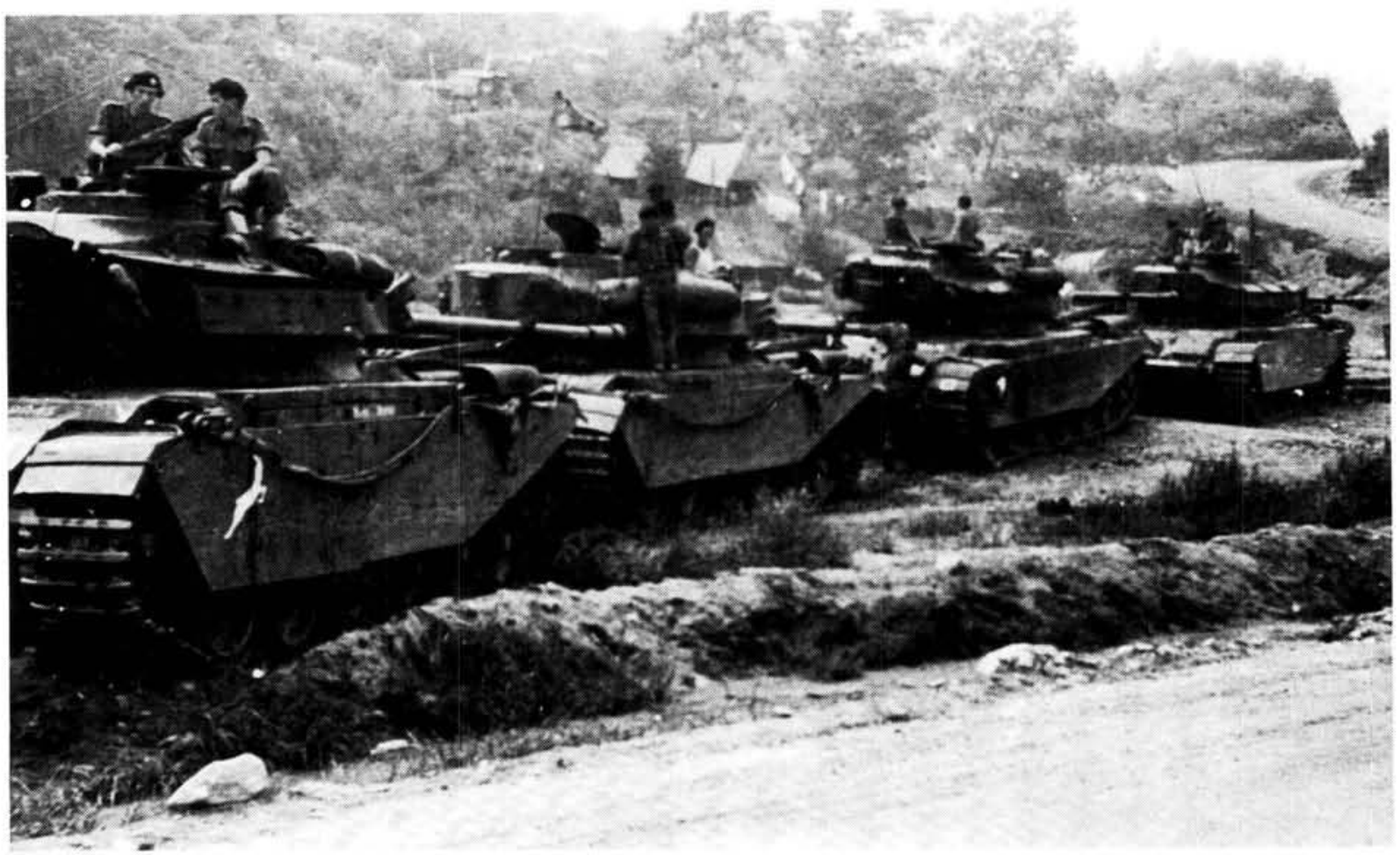

U.N. tanks moving back from the demilitarized zone after the signing of the truce in Korea and the drawing of the "Iron Curtain" in Asia

(SADF Archives 76100 5145)

However, when an organization is formed for the sole purpose of defence against an external enemy, such as NATO and WTO, being an outward-orientated system, it cannot be called a collective security system as such, but rather a system of collective defence or a system of selective security. ${ }^{31}$

\section{The North Atlantic Treaty Organization (NATO)}

Concerned with the security of Western Europe, statesmen, after the failure of the United Nations, began to look for other means of security, to halt the influence of communism pushing into the heart of Europe. This led to the development of regional organizations for collective defence. ${ }^{32}$

The NATO agreement was signed in 1949 a year after the Berlin Blockade, the contracting parties being Belgium, Canada, Denmark, France, Iceland, Italy, Luxembourg, the Netherlands, Norway, Portugal, the United Kingdom, and the United States; and with the inclusion of West Germany, Greece, and Turkey, in NATO, the rigid polarization of Europe was completed. The NATO alliance is neither a general international organization nor a collective security system, as if it had been the latter, the organization would be primarily concerned with regulating conflict amongst its members. ${ }^{33}$ The NATO is therefore, what we would call a collective defence system.

\section{Article 5 of the North Atlantic Treaty:}

The Parties agree that an armed attack against one or more of them in Europe or North America shall be considered an attack against them all, and consequently they agree that, if such an armed attack occurs, each of them, in exercise of the right of individual or collective self-defence recognized by Article 51 of the Charter of the United Nations, will assist the Party or Parties so attacked by taking forthwith, individually and in concert with the other Parties, such action as it deems necessary, including the use of armed force, to restore and maintain the security of the North Atlantic area. ${ }^{34}$

American Senator Vanderberg sums up the value of NATO:

"I still consider collective security the only possible way that our own United States can

31. Ibid., pp. 16-17

32. Pick, O., and Critchley, J.: op cit., pp. 38-9.

33. Fedder, Edwin, H.: NATO: The Dynamics of Alliance in the Postwar World, p. 2.

34. Pick, O., and Critchley, J.: op cit., p. 44. 


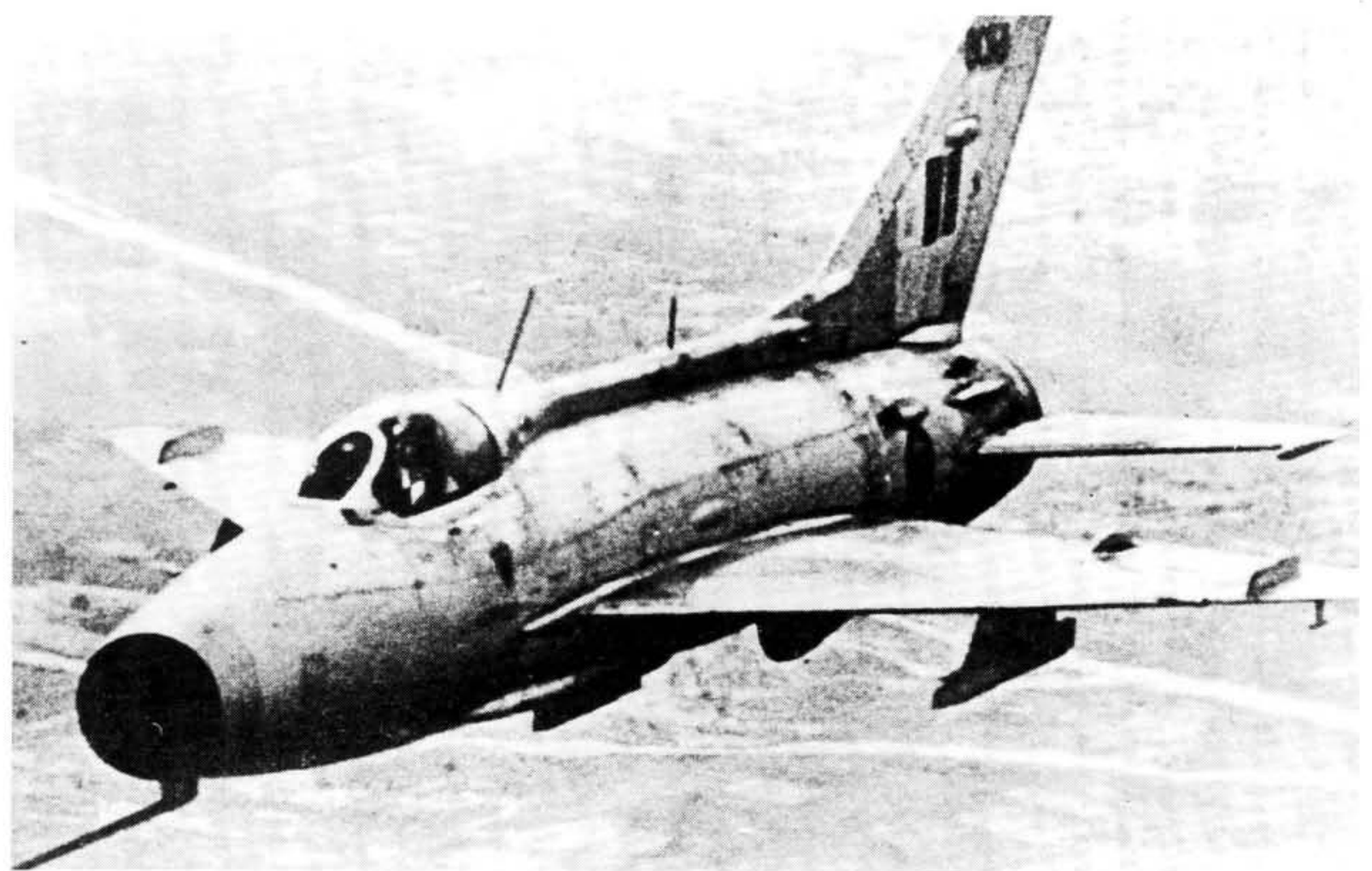

The MiG 21F (fishbed) entered service in 1959 being delivered to India, Finland and the Warsaw Pact states (SADF archives 781001193)

contribute to the prevention of the awful course of World War III ... I consider the North Atlantic Pact to be the indispensible key to our own national security as well as to the peace of the free world. ${ }^{35}$

\section{The Warsaw Treaty Organization (WTO)}

When West Germany had been admitted as a member of NATO, and was permitted to re-arm herself, Russia saw this as a threat and so, on 14 May 1955 - only five days after West Germany's admission to NATO - Russia set up her own military alliance. This became known as the Warsaw Treaty Organization and included the USSR, Albania, Bulgaria, Czechoslovakia, East Germany, Hungary, Poland, and Rumania ${ }^{36}$. Europe was once again polarized in two armed groups.

The texts of both the NATO and the WTO ailiances, stress the security, "although the Preamble of the Warsaw treaty emphasizes the need for an all-European collective security system, describing its own purpose as a holding operation pending the creation of such a system" ${ }^{37}$

\section{The Constellation of Southern African States (CONSAS)}

The Constellation of Southern African States is an example of a regional security alliance, and unlike both NATO and WTO, it is at the moment concerned with the internal restriction of conflict between member states, and at the same time protect the member states from the communistic onslaught in the region.

The independence of both Mozambique and Angola in 1975 resulted in a shifting of the balance of power in Southern Africa, and the decrease in the number of "buffer states" around South Africa. After the rapid decline of Portugese colonialism in Southern Africa and an unsuccessful attempt at detente with the OAU, South Africa adopted a policy of 'Total Strategy', the ultimate aim of which is the establishment of an anti-marxist grouping - a 'Constellation of Southern African States' ${ }^{38}$

35. Naidu, M.V.: op cit., p. 6.

36. Pick, O., and Critchley, J.: op cit., p. 39.

37. Ibid., p. 43.

38. Eduardo de Silva: Mozambican Socialism and the Nkomati Accord. 


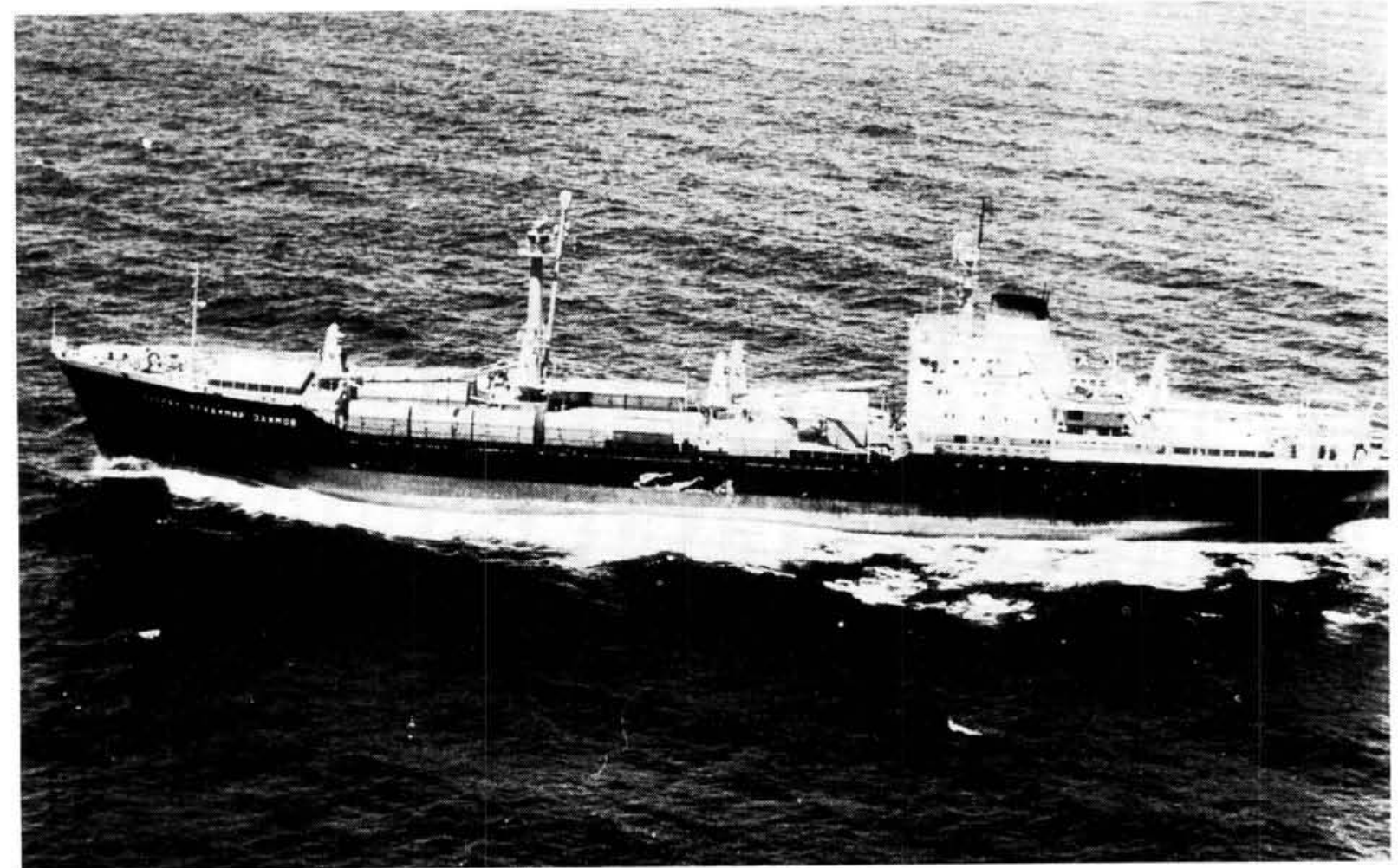

The Soviet freighter, "General Vladimir Zaimov" was sighted south of Durban on 4 November 1975 carrying six MIG-23 (SADF Archives 79100 1050) aircraft fuselage crates and twelve MiG-23 aircraft associated crates.

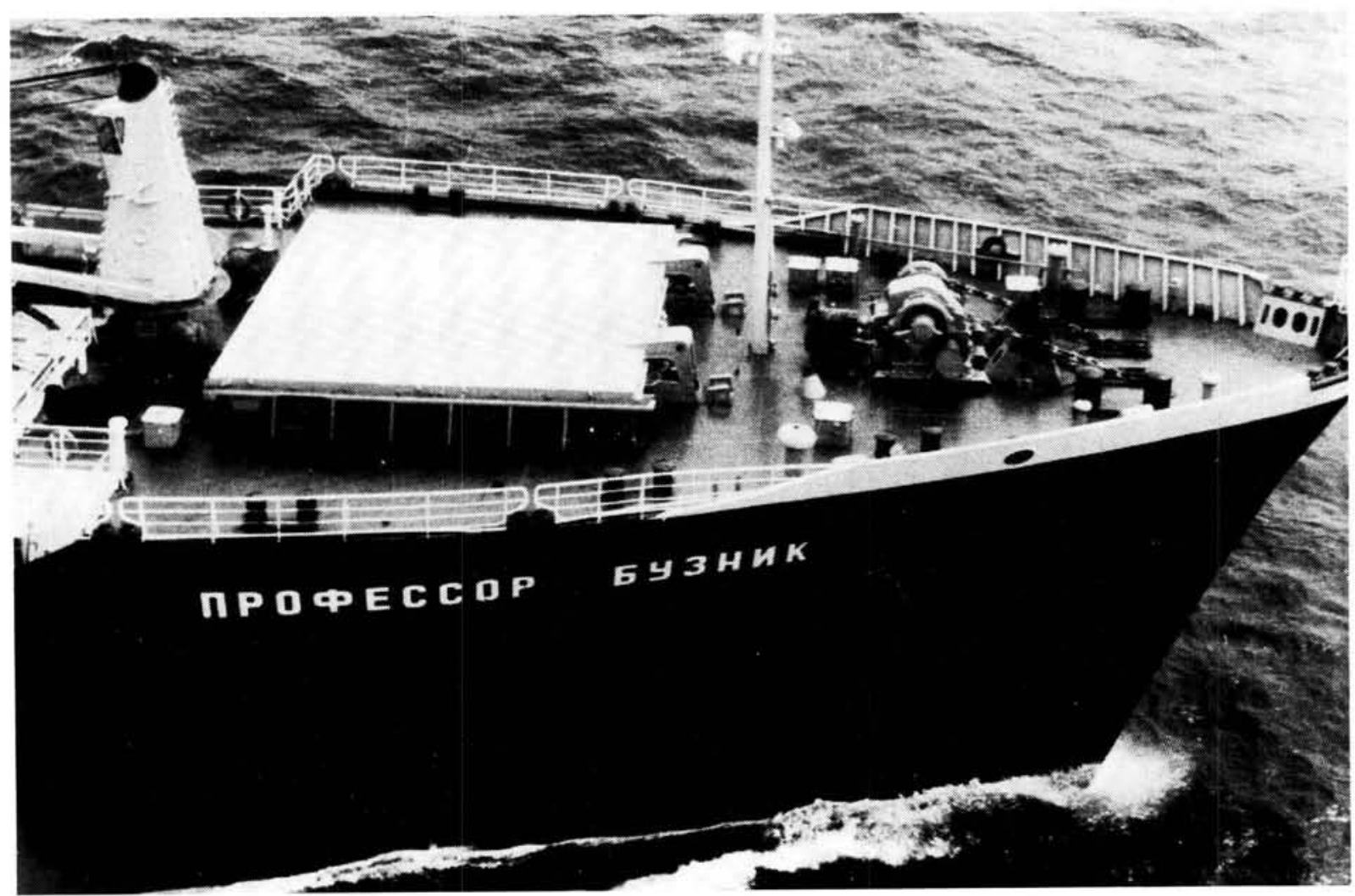

The "Professor Buznik" was sighted 60 miles south of Mossel Bay on 25 November 1975, carrying on deck six MIG-21 aircraft crates, workshop vans, a mobile radar van, two canvas covered trucks and 8 other highside trucks.

(SADF archives 79100 1051) 


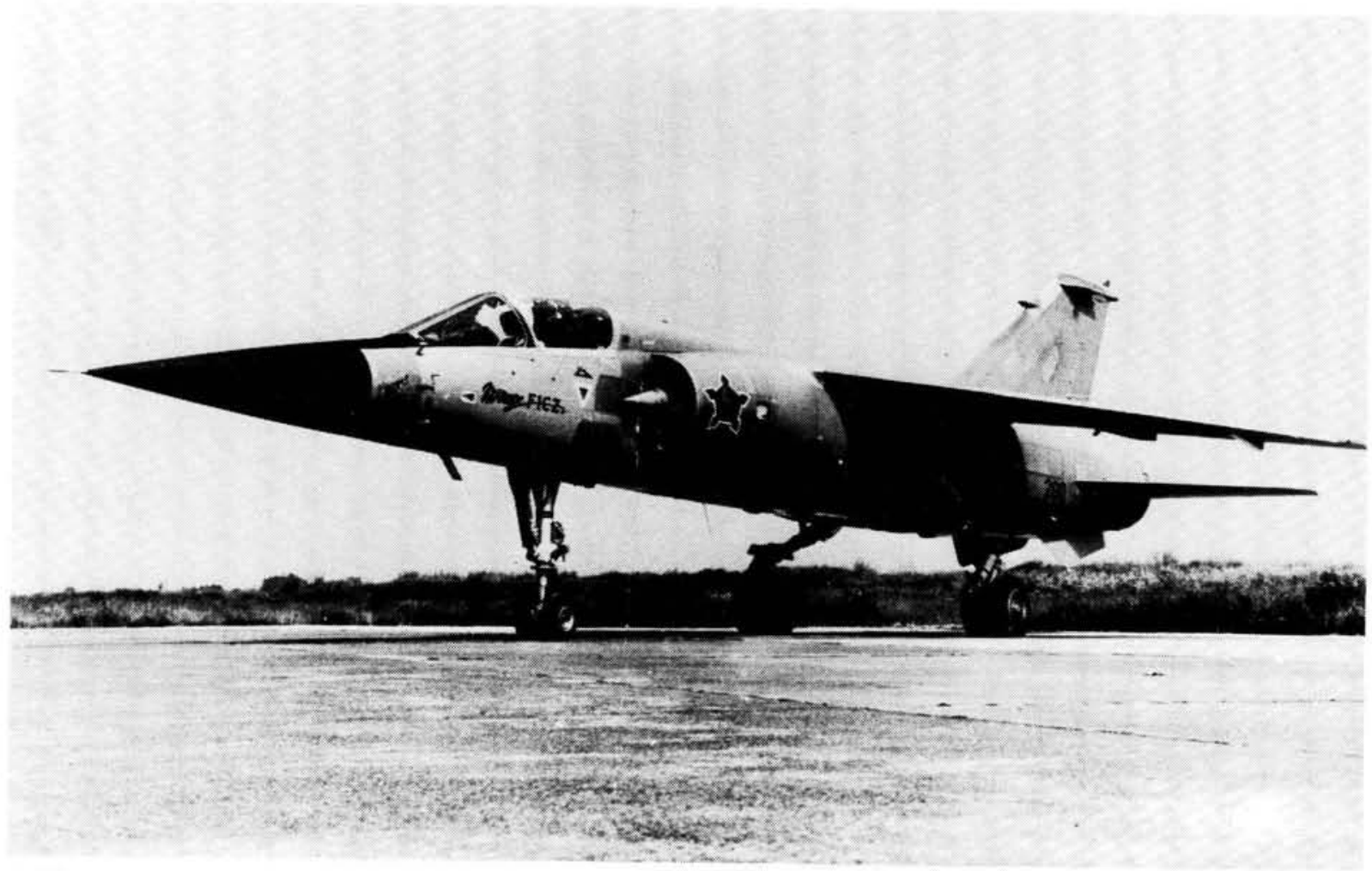

\begin{abstract}
A Mirage FICZ (Mark 1) of the SA Air Force. From 1973 France supplied these aircraft to a number of countries including (SADF archives 791000 719) South-Africa, Kuwait, Iraq, Ecuador and Egypt.
\end{abstract}

South African Prime Minister, Mr P.W. Botha, stated at the 1982 National Party Federal Congress in Bloemfonein that "the South African Government is determined to maintain the Republic of South Africa's military preparedness and to maintain domestic order. We do not underestimate the powers which wish to destabilize our country. But they will act wisely if they do not underestimate our capabilities... when we advocate the establishment of a Confederation of Southern African States we take cognisance of the principles of self-determination and the will not to be subjected to and dominated by others. In a Confederation of Southern African States self-respect and mutual respect for one another will be a prereqisite for co-operation. ${ }^{39}$

\section{Conclusion:}

Due to the fact that the ideal assumptions, which are necessary for an effective collective security, can never be attained in practice, the attention of all interested parties is being drawn to the concept of the regional collective defence alliance.

39. Botha, P.W.: Speech delivered at the N.P. Federal Congress, Bloemfontein, 30-31 July 1982.
These alliances are far more practical and realistic in their nature, while still containing some of the aspects of the collective security system.

The alliance is a lot more dangerous than collective security, as while the latter implies the absence of all alliances, the former means division or polarization of nations into two or more armed camps. And as we can learn from the events running up to the First World War, these groups of defensive alliances can so easily become offensive alliances, and result in war.

The regional collective defence alliance is the synthesis of the balance of power and collective security theories, which have proved exceptionally dangerous and unrealistic; and it is in this synthesis that our contemporary situation is going to have to find a settlement - and if possible a peaceful one.

* Lt I.J. van der Waag B.A. Hons. is attached to the SADF Archives.

\section{Bibliography}

BARNARD, L.D.: Konflik en orde in internasionale verhoudinge. Johannesburg, 1978.

BOTHA, P.W.: Speech delivered at the NP Federal Congress, Blomfontein, 30-31 July 1982.

BUTTERFIELD, H., and WRIGHT, M. (eds): Diplomatic Investigations; Essays in the Theory of International Politics. Cambridge (Mass), 1968.

CANTOR, R.D.: Introduction to International Policis. Itusca, Illinois, 1976. 
COULOUMBIS, T.A., AND WOLFE, J.A.: Introduction to International relations; Power and Justice. Englewood Cliffs, New Jersey, 1982

DA SILVA, E.: Mozambican Socialism and the Nkomati Accord (work in Progress, No 32, 1984).

DUCHACEK, I.D.: Nations and Men; International Politics Today.

FEDDER, E.H.: NATO; The Dynamics of Alliance in the Postwar World. New York, 1973

GRANT, A.J., and TEMPERLEY, H.: Europe in the Nineteenth and Twntieth Centuries, 1789-1950. Singapore, 1952.

HAAS, E.B.: Tangle of Hopes; American Commitments and World Order.

HARTMAN, F.H.: World in Crisis; Reading in International Relations. New York, 1967.
MORGENTHAU, H.J.: Politics Among Nations; a struggle for power and peace. New York, 1973

NAIDU, M.V.: Collective Security and the United Nations; a definition of the UN security system. New York, 1974.

PALMER, N.D., and PERKINS, H.C.: International Relations; The World Community in Transition. Boston, 1957.

PICK, 0., and CRITCHLEY, I.: Collective Security. London, 1974

RODEE ET AL: Introduction to Political Science. Tokyo, 1983.

VAN DYKE, V.: International Relations. New York, 1966

WILLIAMS, E.N.: Dictionary of English and European History, 1485-1789. Hamondsworth. Middlesex, 1980. 